\title{
Efficacy of Various Fungal and Bacterial Biocontrol Organisms for Control of Fusarium Wilt of Tomato
}

\author{
Robert P. Larkin and Deborah R. Fravel, USDA-ARS, Biocontrol of Plant Diseases Laboratory, Beltsville, MD \\ 20705
}

\begin{abstract}
Larkin, R. P., and Fravel, D. R. 1998. Efficacy of various fungal and bacterial biocontrol organisms for control of Fusarium wilt of tomato. Plant Dis. 82:1022-1028.

Numerous fungi and bacteria, including existing biocontrol strains with known activity against soilborne fungal pathogens as well as isolates collected from the roots and rhizosphere of tomato plants growing in the field, were tested for their efficacy in controlling Fusarium wilt of tomato. Tomato seedlings were treated with the potential biocontrol agents in the greenhouse and transplanted into pathogen-infested field soil. Organisms tested included nonpathogenic strains of Fusarium spp., Trichoderma spp., Gliocladium virens, Pseudomonas fluorescens, Burkholderia cepacia, and others. Specific nonpathogenic isolates of $F$. oxysporum and $F$. solani collected from a Fusarium wilt-suppressive soil were the most effective antagonists, providing significant and consistent disease control (50 to $80 \%$ reduction of disease incidence) in several repeated tests. These isolates also were equally effective in controlling Fusarium wilt diseases of other crops, including watermelon and muskmelon. Other organisms, including isolates of $G$. virens, T. hamatum, P. fluorescens, and B. cepacia, also significantly reduced Fusarium wilt compared to disease controls (30 to $65 \%$ reduction), but were not as consistently effective as the nonpathogenic Fusarium isolates. Commercially available biocontrol products containing $G$. virens and $T$. harzianum (SoilGard and RootShield, respectively) also effectively reduced disease (62 to $68 \%$ reduction) when granules were incorporated into potting medium at $0.2 \%$ (wt/vol). Several fungal and bacterial isolates collected from the roots and rhizosphere of tomato plants also significantly reduced Fusarium wilt of tomato, but were no more effective than other previously identified biocontrol strains. Combinations of antagonists, including multiple Fusarium isolates, Fusarium with bacteria, and Fusarium with other fungi, also reduced disease, but did not provide significantly better control than the nonpathogenic Fusarium antagonists alone.
\end{abstract}

Additional keywords: biological control, Cladorrhinum foecundissimum, Laetisaria arvalis, Lycopersicon esculentum, Stilbella aciculosa

Fusarium wilt diseases, caused by pathogenic formae speciales of the soilinhabiting fungus Fusarium oxysporum Schlectend.:Fr., can cause severe losses in a wide variety of crop plants. On tomato, two symptomologically distinct forms of the pathogen can cause either a vascular wilt (F. oxysporum f. sp. lycopersici W. C. Snyder \& H. N. Hans.) or a crown and root rot (F. oxysporum f. sp. radicis-lycopersici W. R. Jarvis \& Shoemaker). Both of these pathogens occur throughout most tomato-

Corresponding author: R. P. Larkin

E-mail: rlarkin@asrr.arsusda.gov

Mention of a trademark or proprietary product does not constitute a guarantee or warranty of the product by the United States Department of Agriculture and does not imply its approval to the exclusion of other products that may be suitable.

Accepted for publication 9 June 1998.

Publication no. D-1998-0720-02R

This article is in the public domain and not copyrightable. It may be freely reprinted with customary crediting of the source. The American Phytopathological Society, 1998. growing areas and either can devastate a crop. Although the use of Fusarium-resistant tomato cultivars can provide some degree of control of these diseases, the occurrence and development of new pathogenic races is a continuing problem, and currently there are no commercially acceptable cultivars with adequate resistance to $F$. oxysporum f. sp. radicis-lycopersici or race 3 of $F$. oxysporum f. sp. lycopersici $(13,14)$. These diseases are generally controlled in tomato (and several other crops) by preplant soil fumigation with methyl bromide $(\mathrm{MBr})$. Tomatoes represent the largest single-crop use of $\mathrm{MBr}$ in the United States, accounting for $25 \%$ of the total $\mathrm{MBr}$ use for soil fumigation, or over 5,000 t/year (45). However, fumigation with $\mathrm{MBr}$ is expensive and not always effective. In addition to other potential health, safety, and environmental risks, $\mathrm{MBr}$ is classified as an ozone-depleting compound and, as required by the Clean Air Act, is scheduled to be removed from the market in the United States by 2001. Therefore, alternative control measures are necessary and need to be made available as soon as possible.
Biological control has potential for the management of these diseases. A variety of soil microorganisms have demonstrated activity in the control of various soilborne plant pathogens, including Fusarium wilt pathogens. Fusarium wilt-suppressive soils are known to occur in many regions of the world, and suppression has generally been shown to be biological in origin. Antagonists recovered from Fusarium wilt-suppressive soils, especially nonpathogenic $F$. oxysporum, have been used to reduce Fusarium wilt diseases of several different crops $(1,18,35,37,39)$. Other biocontrol fungi, such as Trichoderma and Gliocladium spp., have been used to control a variety of fungal pathogens, including Rhizoctonia, Pythium, Sclerotinia, Sclerotium, and Fusarium spp. (11,26,27,30, $32,44)$, and may also be effective against Fusarium wilt diseases $(5,34,43,49)$. In addition, several lesser-known groups of biocontrol fungi, including Laetisaria, Stilbella, Cladorrhinum, and Penicillium spp., have been used to control soilborne pathogens $(6,25,28,29)$ and also may have activity against Fusarium diseases. Rhizobacterial strains of Pseudomonas, Burkholderia, and Bacillus spp. also have been used to reduce disease caused by a variety of soilborne pathogens $(47,48)$, including Fusarium spp. (12,31,40,42,46). Although many different biocontrol strains have shown potential for some degree of control of Fusarium diseases, strains which can provide the best control of Fusarium wilt of tomato and have potential for effective implementation in commercial agriculture have not yet been identified.

It has been suggested that microorganisms isolated from the root or rhizosphere of a specific crop may be better adapted to that crop and may provide better control of diseases than organisms originally isolated from other plant species (3). Such plantassociated microorganisms may make better biocontrol agents because they are already closely associated with and adapted to the plant or plant part as well as the particular environmental conditions in which they must function. The screening of such locally adapted strains has yielded improved biocontrol in some cases (3).

The use of combinations of multiple antagonist organisms also may provide improved disease control over the use of single organisms. Multiple organisms may enhance the level and consistency of control by providing multiple mechanisms of 
action, a more stable rhizosphere community, and effectiveness over a wider range of environmental conditions. In particular, combinations of fungi and bacteria may provide protection at different times or under different conditions, and occupy different or complementary niches. Such combinations may overcome inconsistencies in the performance of individual isolates. Several researchers have observed improved disease control using various combinations of multiple compatible biocontrol organisms $(7,8,38)$. Lemanceau and Alabouvette and others $(19,22,36)$ have demonstrated enhanced biocontrol of Fusarium wilt by combining certain nonpathogenic strains of $F$. oxysporum with fluorescent strains of Pseudomonas.

The objectives of this research were to examine existing biocontrol strains, including commercial formulations, with known activity against soilborne fungal pathogens for their efficacy in controlling Fusarium wilt of tomato, as well as to isolate potential new antagonists from the rhizosphere and roots of field-grown tomato plants and screen them for their biocontrol capabilities. In addition, preliminary investigations on the potential benefits of combining various antagonist organisms for the control of Fusarium wilt were performed. This research was conducted as a first step toward the development of effective biological control as an alternative strategy for the management of $\mathrm{Fu}$ sarium wilt diseases. A preliminary report of aspects of this work has been published (16).

\section{MATERIALS AND METHODS}

Known biocontrol isolates. Various fungi and bacteria with known biocontrol activity against soilborne fungal pathogens, including biocontrol isolates of Fusarium spp., Trichoderma spp., Gliocladium virens, Pseudomonas spp., Burkholderia cepacia, and others, were used in screening tests. Isolates of Fusarium spp. included several $F$. oxysporum and $F$. solani isolates collected from a Fusarium wilt-suppressive soil in Florida in previous studies (18) and F. oxysporum isolate Fo47 obtained from C. A. Alabouvette (Dijon, France; 1). Isolates of T. hamatum (TRI-4), T. harzianum (Th-87), T. viride (Tv-101), Laetisaria arvalis (Zh-1), Cladorrhinum foecundissimum (Cf-1), and Stilbella aciculosa (112B2), as well as numerous isolates of $G$. virens (Gl-2 to G1-21), were obtained from the collection of the United States Department of Agriculture-Agricultural Research Service (USDA-ARS), Biocontrol of Plant Diseases Laboratory (BPDL). Numerous isolates of Burkholderia cepacia, Pseudomonas fluorescens, and $P$. corrugata originally isolated from corn and soybean roots or soil were obtained from K. P. Hebbar, BPDL. Additional isolates of $P$. fluorescens (Pf-5 and C7) were obtained from J. E. Loper (Corvallis, OR) and C. Alabou- vette, respectively. Fungal isolates were grown on potato dextrose agar (PDA) and bacterial isolates were grown on nutrient agar (NA). Commercially available formulations of $G$. virens strain Gl-21 (SoilGard, Thermo-Trilogy Corp., Columbia, MD) and $T$. harzianum strain T-22 (RootShield, Bio-Works, Inc., Geneva, NY) also were tested for efficacy in this system.

Isolation of soil and root organisms. Soil and roots were collected from established tomato field plots that had been planted with tomatoes for at least two consecutive years at the Beltsville Agricultural Research Center, Maryland. Tomato field soil was placed in flats in the greenhouse and planted with tomato seeds. After 2 weeks, seedlings were harvested and root systems with adhering rhizosphere soil were used to isolate rhizosphere and rhizoplane organisms as previously described (17). Segments of root systems collected directly from the field also were used. Root sections of approximately $0.2 \mathrm{~g}$ were added to $100 \mathrm{ml}$ sterile water in flasks and shaken on a rotary shaker at 150 rpm for $30 \mathrm{~min}$. Root segments, as well as a 10-fold dilution series of the resulting water suspensions, were plated on various general and selective media to recover root organisms. General bacteria were recovered using tryptic soy agar and NA, whereas Pseudomonas and Burkholderia spp. were preferentially recovered using King's medium B with antibiotics (41) and P. cepacia azaleic acid tryptamine (PCAT) medium (2), respectively. Trichoderma and Gliocladium spp. were recovered on a Trichoderma-selective medium (9), and Fusarium spp. were recovered using Komada's Fusarium-selective medium (KM; 15). Other fungi were recovered using PDA amended with $1 \mathrm{ml}$ tergitol and $50 \mathrm{mg}$ chlortetracycline per liter.

Screening trials. Tomato seeds of the cultivar "Bonny Best" were planted in soilless potting mix (Redi-Earth, ScottsSierra Inc., Marysville, $\mathrm{OH}$ ), infested with the antagonist to be tested, and grown in seedling plug trays (plug size 3.4 by 3.4 by $5 \mathrm{~cm}, 98$ plugs/tray). For initial screenings, isolates of nonpathogenic Fusarium spp. were grown for 7 to 10 days on PDA and 3 $\mathrm{ml}$ conidial suspensions of approximately $10^{6}$ conidia/ml were added to each plug cell. Fungal antagonists Trichoderma and Gliocladium spp., L. arvalis, C. foecundissimum, and $S$. aciculosa were added to potting mix as wheat bran culture germlings (27) at the rate of $1 \%$ (wt/vol). Germlings were prepared by adding cell or conidial suspensions of approximately $10^{6}$ $/ \mathrm{ml}$ to autoclaved, moistened wheat bran (1:1 bran:water wt/vol) and incubated under ambient conditions $\left(25^{\circ} \mathrm{C}\right)$ for 3 to 5 days. Bacterial antagonists were grown on NA for 3 to 5 days, then $3 \mathrm{ml}$ of an aqueous suspension of approximately $10^{8}$ bacterial cells $/ \mathrm{ml}$ was added per plug of potting mix. Five tomato seeds were planted in each cell of the plug tray and maintained in the greenhouse. After 2 weeks, plugs containing the tomato plants were transplanted into $10-\mathrm{cm}$-diameter pots containing nonsterile field soil (Galestown gravelly loamy sand) infested with the Fusarium wilt pathogen. Pathogen inoculum consisted of a race 1 strain of $F$. oxysporum f. sp. lycopersici (strain IA-7 from R. W. Schneider, Louisiana State University) grown in a liquid culture of $1 \%$ ground soybean hull fiber (Dietfiber soy fiber, Lauhoff Grain Co., Danville, IL). Cultures were grown for 10 to 14 days on a rotary shaker at 150 rpm at $25^{\circ} \mathrm{C}$, blended, and propagule counts determined on a hemacytometer. Inoculum consisted of a mixture of conidia and chlamydospores and was added to field soil at a rate of $10^{4} \mathrm{CFU} / \mathrm{g}$ soil. Subsequent screening assays involving nonpathogenic Fusarium spp. used the liquid soybean hull fiber cultures to produce the antagonist as well as the pathogen inoculum as described above. Commercial biocontrol preparations of $G$. virens and T. harzianum (SoilGard and RootShield granules, $1 \times 10^{6}$ and $1 \times$ $10^{7} \mathrm{CFU} / \mathrm{g}$ inoculum, respectively) were incorporated into Redi-Earth prior to planting tomato seeds at the rates of 0.05 , $0.1,0.2$, and $0.5 \%$ (wt/vol). An incorporation rate of $0.5 \%$ corresponded to final propagule counts of approximately $7.5 \times$ $10^{4}$ and $1 \times 10^{5} \mathrm{CFU} / g$ soilless mix for SoilGard and RootShield, respectively.

Each treatment consisted of five replicate pots of four to five plants/pot. Disease was monitored for 4 to 6 weeks and assayed as the total percentage of seedlings showing any wilt symptoms due to the pathogen (yellowing and dropping of leaves, vascular discoloration, wilting, and so on). Stem sections of wilted seedlings were surface-disinfested in $0.5 \%$ sodium hypochlorite and plated on KM to confirm the presence of the wilt pathogen. Stem sections of asymptomatic plants were also plated at the conclusion of the experiment to evaluate potential pathogen infection. Additional assays on watermelon and muskmelon were conducted in the same manner using a race 1 isolate of $F$. oxysporum f. sp. niveum (strain CS93-8 from D. L. Hopkins, University of Florida) and watermelon cultivar "Crimson Sweet," and a race 1 isolate of $F$. oxysporum f. sp. melonis (strain 660K from E. Dutkey, University of Maryland) and melon cultivar "Goldstar."

Biocontrol isolates that were most effective in individual assays were tested in various combinations using the same procedures as with individual isolates. Combinations tested included multiple Fusarium isolates; Fusarium isolates combined with bacteria, such as $P$. fluorescens or B. cepacia; and Fusarium isolates combined with $G$. virens. Treatments were prepared such that the total propagule counts for the combinations were the same as for the individual treatments. 
Statistical analyses. All experiments were conducted at least twice. Statistical analyses were conducted using the general linear models procedures of the Statistical Analysis Systems version 6.08 (SAS Institute, Inc., Cary, NC). Experiments were

analyzed using standard analysis of variance (ANOVA) with interactions. Significance was evaluated at $P<0.05$ for all tests. Mean separation was accomplished using Fisher's protected least significant difference test. All data expressed as per-

Table 1. Summary of potential biocontrol organisms tested for their ability to reduce Fusarium wilt of tomato in field soil transplant tests

\begin{tabular}{lcccc}
\hline & & \multicolumn{3}{c}{ Reduction of disease $^{\mathbf{z}}$} \\
\cline { 5 - 5 } Organism group & $\begin{array}{c}\text { Total isolates } \\
\text { tested }\end{array}$ & $\begin{array}{c}\text { Effective } \\
\text { isolates }\end{array}$ & $\begin{array}{c}\text { Range of } \\
\text { reduction }\end{array}$ & $\begin{array}{c}\text { Average } \\
\text { reduction }\end{array}$ \\
\hline Known biocontrol isolates & & & & \\
$\quad$ Fusarium spp. & 10 & 8 & $50-100 \%$ & $66.6 \%$ \\
Trichoderma and Gliocladium spp. & 14 & 4 & $37-75 \%$ & $57.3 \%$ \\
Pseudomonas spp. & 8 & 3 & $30-63 \%$ & $46.1 \%$ \\
Burkholderia spp. & 10 & 5 & $19-57 \%$ & $36.4 \%$ \\
$\quad$ Other & 4 & 2 & $35-61 \%$ & $49.2 \%$ \\
Field isolates & & & & \\
$\quad$ Bacteria & 120 & 29 & $30-65 \%$ & $43.2 \%$ \\
Fungi & 60 & 14 & $40-66 \%$ & $45.1 \%$ \\
\hline
\end{tabular}

${ }^{\mathrm{z}}$ Values represent the number of isolates within each group that significantly $(P<0.05)$ reduced disease incidence (relative to pathogen-infested control soil), the range of percent reduction of disease for effective isolates, and the average percent reduction of disease for all effective isolates in that group.

Table 2. Isolates of nonpathogenic Fusarium spp. most effective in reducing Fusarium wilt of tomato in a greenhouse test

\begin{tabular}{lccrr}
\hline Isolate & \% wilt & \% reduction & Species & Source $^{\mathrm{y}}$ \\
\hline Pathogen-only & $56.7 \mathrm{a}^{\mathrm{z}}$ & 0 & & \\
Fo47 & $28.0 \mathrm{~b}$ & 50.6 & F. oxysporum & France, Fusarium-suppressive soil \\
CS-21 & $26.5 \mathrm{~b}$ & 53.3 & F. oxysporum & Florida, wilt-suppressive soil \\
CS-10 & $17.2 \mathrm{bc}$ & 69.7 & F. oxysporum & Florida, wilt-suppressive soil \\
CS-6 & $12.9 \mathrm{bc}$ & 77.3 & F. solani & Florida, wilt-suppressive soil \\
CS-2 & $12.4 \mathrm{bc}$ & 78.1 & F. oxysporum & Florida, wilt-suppressive soil \\
CS-24 & $8.6 \mathrm{c}$ & 84.9 & F. oxysporum & Florida, wilt-suppressive soil \\
CS-20 & $6.7 \mathrm{c}$ & 88.2 & F. oxysporum & Florida, wilt-suppressive soil \\
CS-1 & $0.0 \mathrm{c}$ & 100 & F. solani & Florida, wilt-suppressive soil \\
\hline
\end{tabular}

${ }^{y}$ Sources: France (1) and Florida $(17,18)$.

${ }^{z}$ Values followed by the same letter are not significantly different $(P<0.05)$ according to Fisher's protected least significant difference $(\mathrm{LSD})$ test $(\mathrm{LSD}=17.7)$.

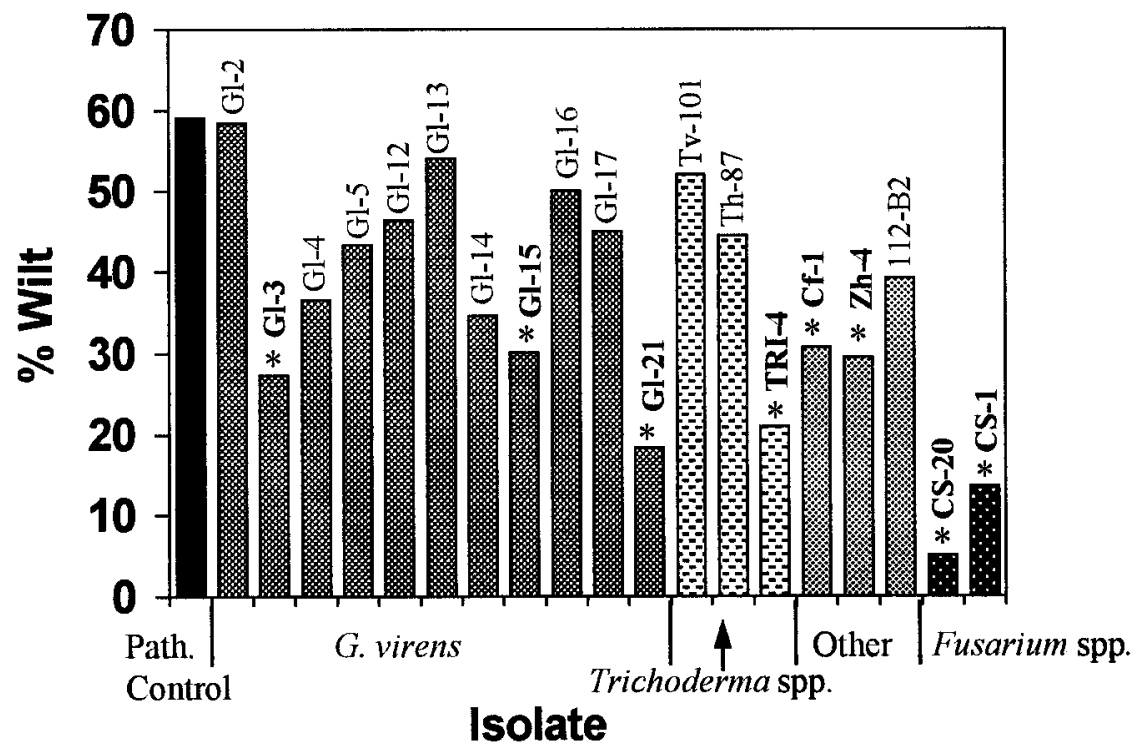

Fig. 1. Development of Fusarium wilt in tomato seedlings as affected by treatments with various biocontrol fungi. Bars topped by an asterisk denote significant reduction of disease relative to the pathogen-infested control treatment according to Fisher's protected least significant difference (LSD) at $P=0.05(\mathrm{LSD}=24)$. Data represent results of a single representative test. centages were arcsine-transformed $\left(\right.$ sine $^{-1}$ $\sqrt{ } x$ ) before analysis. Since repeated tests yielded similar results, data from a single representative experiment are presented.

\section{RESULTS}

Known biocontrol isolates. Individual isolates within all groups of the known biocontrol organisms, including isolates of $F$. oxysporum, T. hamatum, G. virens, $P$. fluorescens, and B. cepacia, significantly reduced Fusarium wilt of tomato in greenhouse tests (Table 1). Reductions in disease incidence ranged from 35 to $100 \%$ relative to the pathogen-infested controls. As a group, the most effective antagonists were the Fusarium isolates collected from wiltsuppressive soils, with 8 of 10 isolates tested reducing disease incidence by 50 to $100 \%$. Isolate Fo47, which was collected from a wilt-suppressive soil in France (1) and is in the process of being developed as a biological control agent for the control of Fusarium diseases in Europe, reduced disease by $50 \%$ in a representative test (Table 2). Several isolates of Fusarium spp. collected from watermelon roots in a wiltsuppressive soil in Florida (18) reduced disease by up to $100 \%$ (Table 2).

In general, the pathogen could not be isolated from stem sections of asymptomatic plants protected by the biocontrol treatments, indicating that the disease assay was effective in identifying all diseased plants, and that the asymptomatic plants were generally free of disease and did not merely represent attenuation of symptom development. These asymptomatic plants continued to remain healthy and developed normally even after the duration of these studies were concluded, suggesting that they would develop into productive fruiting plants. On the other hand, symptoms continued to worsen in diseased plants over time, eventually resulting in loss of all leaves and death of the plant.

Several other fungal antagonists, including $G$. virens strain Gl-3, Gl-15, and Gl-21; T. hamatum strain TRI-4; L. arvalis strain $\mathrm{Zh}-4$; and $C$. foecundissimum strain Cf-1; also significantly reduced Fusarium wilt in these screening tests (Fig. 1). The most effective of these other fungal antagonists were G. virens strain G1-21, which reduced wilt incidence by $68 \%$, and T. hamatum strain TRI-4, which reduced wilt incidence by $64 \%$. However, even these isolates were not quite as effective as Fusarium isolates CS-20 and CS-1, which reduced wilt by 92 and $77 \%$, respectively, in a corresponding test (Fig. 1). Several rhizobacterial isolates, including biocontrol strains of B. cepacia, P. fluorescens, and $P$. corrugata, also significantly reduced Fusarium wilt compared to the pathogenonly control (Fig. 2). However, although selected bacterial isolates reduced disease by 30 to $65 \%$ in individual tests, these isolates, in general, were not as effective or 
consistent in the reduction of disease as the nonpathogenic $F$. oxysporum isolates or some of the other fungal antagonists in repeated tests.

The commercial biocontrol formulations, SoilGard and RootShield, each significantly reduced Fusarium wilt disease when granules were incorporated into the potting medium at the $0.2 \%$ level, but not at 0.1 or $0.05 \%$ (Table 3). At the $0.2 \%$ level, disease control (62 to $68 \%$ reduction) was comparable to that provided by Fusarium isolates CS-20 and CS-1 (73 to $78 \%$ reduction). SoilGard also was effective at the higher incorporation rate of $0.5 \%$, whereas RootShield was not consistently effective at this higher rate in initial tests. However, in an additional test of SoilGard and RootShield at 0.2 and $0.5 \%$ incorporation rates, both formulations significantly reduced $(P<0.05)$ disease incidence compared to the pathogen-infested controls. Both formulations provided comparable disease reduction at both incorporation rates (rate effect and rate $\times$ treatment interaction not significant), averaging 27.8 and $38.5 \%$ disease incidence for the SoilGard and RootShield treatments, respectively, compared to $83.4 \%$ in the control treatment, representing reductions in disease incidence of 66.7 and $53.8 \%$ by SoilGard and RootShield, respectively. In this same test, disease incidence in CS-20treated plants was $15.6 \%$, for a disease reduction of $81.3 \%$ relative to the pathogen-infested controls.

Field isolates. A total of 180 isolates, including 120 bacteria and 60 fungi, were collected from tomato roots and rhizosphere soil and tested for their ability to control Fusarium wilt of tomato in greenhouse screening tests. Of the 60 fungi tested, 18 were isolates of Fusarium spp., 24 were Trichoderma- or Gliocladium-type fungi, and 18 were unidentified. Bacterial isolates consisted of various unidentified rhizobacteria, including numerous Pseudomonas and Burkholderia-type isolates. Numerous isolates of these fungi and bacteria also significantly reduced Fusarium wilt of tomato by 30 to $65 \%$ relative to pathogen-infested controls (Table 1). Approximately $23 \%$ of the fungal isolates tested, including 7 of 18 Fusarium (39\%), 5 of 24 Gliocladium or Trichoderma (21\%), and 2 of 18 other fungi (11\%), as well as $24 \%$ of the bacterial isolates tested, significantly reduced Fusarium wilt. However, since the level of disease control provided by these field isolates was generally not as good as and certainly no better than that provided by the nonpathogenic Fusarium spp. and several other of the known biocontrol isolates, no further tests were performed using these field isolates.

Additional screening tests. Because the nonpathogenic Fusarium isolates were the most effective antagonists in all screening tests, additional tests concentrated primarily on these isolates. Subsequent testing on three different hosts of Fusarium wilt (tomato, watermelon, and muskmelon) determined that these Fusarium isolates were equally effective in reducing Fusarium wilt disease (50 to $80 \%$ disease reduction) on all three host crops (Table 4). Disease reduction by each isolate was consistent across all three hosts (host $\times$ treatment interaction was not significant), indicating no detectable host-specific effect on disease reduction. As in previous tests on tomato alone, isolates CS-1 and CS-20 were consistently the most effective isolates on all hosts, resulting in $>80 \%$ overall reduction of disease incidence.

In preliminary tests using combinations of antagonists, including multiple Fusarium strains, bacteria with Fusarium, and other fungi (G. virens) with Fusarium, all combinations tested significantly reduced Fusarium wilt of tomato relative to pathogen controls (Fig. 3). However, no combination of antagonists, including com- binations of Fusarium and fluorescent pseudomonads, provided consistent or significant improvement on the disease control provided by nonpathogenic Fusarium strains alone. In fact, most combinations were not quite as effective in reducing disease incidence as were the most effective isolates of Fusarium alone, although there were no statistically significant $(P>0.05)$ differences among all the biocontrol treatments.

\section{DISCUSSION}

Several isolates of nonpathogenic Fusarium spp. collected from a Fusarium wilt-suppressive soil previously shown to reduce Fusarium wilt of watermelon (18) also were found to be highly effective in the control of Fusarium wilt of tomato, as well as other crops. Isolates CS-20 and CS1 were the most effective antagonists, consistently providing from 50 to $80 \%$ reduction of disease relative to pathogen-treated

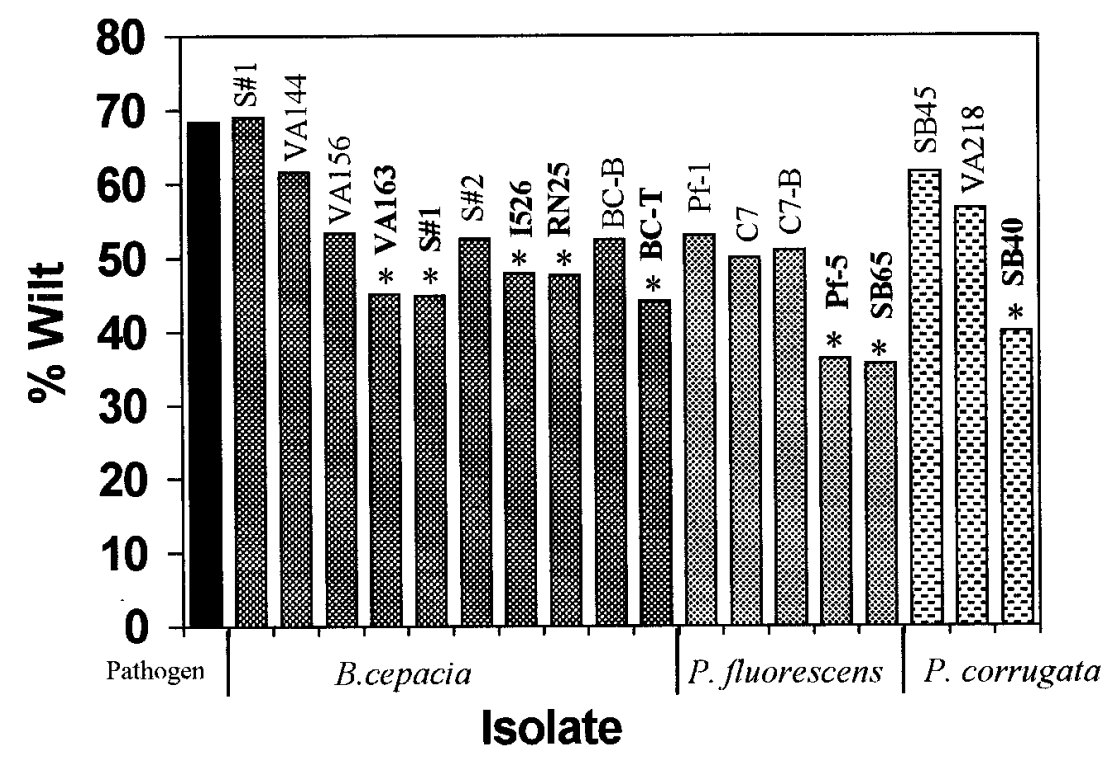

Fig. 2. Development of Fusarium wilt in tomato seedlings as affected by treatments with various biocontrol bacteria. Bars topped by an asterisk denote significant reduction of disease relative to the pathogen-infested control treatment according to Fisher's protected least significant difference (LSD) at $P=0.05(\mathrm{LSD}=18)$. Data represent results of a single representative test.

Table 3. Development of Fusarium wilt of tomato as affected by biocontrol treatments with two commercially available formulations at four application rates and with antagonistic Fusarium isolates

\begin{tabular}{llcc}
\hline Treatment & Rate $^{\mathbf{y}}$ & \% wilt & \% reduction \\
\hline Pathogen-only & & 73.4 & 0 \\
SoilGard & 0.05 & 64.4 & 12 \\
& 0.1 & 47.6 & 39 \\
& 0.2 & $23.2^{* \mathrm{z}}$ & 68 \\
RootShield & 0.5 & $21.4^{*}$ & 71 \\
& 0.05 & 57.0 & 22 \\
& 0.1 & 55.0 & 25 \\
CS-20 (F. oxysporum) & 0.2 & $28.0^{*}$ & 62 \\
CS-1 $(F$. solani $)$ & 0.5 & 43.0 & 41 \\
LSD $(P=0.05)$ & & $20.0^{*}$ & 73 \\
\hline
\end{tabular}

${ }^{\mathrm{y}}$ Rate $=\%$ incorporation $(\mathrm{wt} / \mathrm{vol})$.

${ }^{\mathrm{z}}$ Values followed by an asterisk are significantly lower $(P<0.05)$ than the pathogen-only control treatment according to Fisher's protected least significant difference (LSD) test. 
control plants over all tests and crops, and as high as 90 to $100 \%$ control in selected individual tests. Isolates of nonpathogenic Fusarium spp. originally isolated from watermelon roots were just as effective in controlling Fusarium wilt on tomato and muskmelon as on watermelon. Preliminary data on basil and spinach (unpublished) also indicated that control is provided for Fusarium wilt diseases on a variety of different crops. This suggests that the mechanism of action is not host-specific. Most of these isolates ( 7 of 8 ) came from a unique wilt-suppressive soil in Florida. This suppressive soil (CSS) developed as a result of prolonged monoculture to a particular cultivar of watermelon, which promoted suppressiveness $(17,18)$. Fusarium isolates collected from this soil were more effective in reducing Fusarium wilt disease, and effective isolates were more abundant in this soil than in a similar nonsuppressive soil (18).

Other previously described biocontrol organisms, including G. virens, T. hamatum, P. fluorescens, and B. cepacia, also demonstrated varying degrees of efficacy in reducing Fusarium wilt of tomato. The most effective of these isolates, $G$. virens strain Gl-21, previously has been used to control damping-off diseases of various crops caused by Pythium ultimum, P. arrhenomanes, Rhizoctonia solani, and others $(26,27,32)$, as well as Sclerotium rolfsii (30). However, this isolate had not been previously shown to be effective against Fusarium wilt diseases. Zhang et al. (49), using different $G$. virens isolates (G-4 and G-6), demonstrated significant reduction of Fusarium wilt of cotton and colonization of roots by $F$. oxysporum. Trichoderma spp., particularly $T$. harzianum, have been effective against diseases caused by $F$. oxysporum in studies by other researchers $(5,34,43)$. In our tests, only the TRI-4 isolate of T. hamatum was effective in reducing disease, whereas isolates Th-87 and Tv-101 of T. harzianum and T. viride, respectively, were not consistently effective. This research also demonstrated for the first time that two other lesser known biocontrol agents, L. arvalis and C. foecundissimum, which had previously been shown to control $R$. solani $(25,28)$ also have biocontrol activity against Fusarium wilt diseases.

Commercial biocontrol formulations of $G$. virens strain Gl-21 (SoilGard) and $T$. harzianum strain T-22 (RootShield) were also effective at reducing disease when incorporated at rates of $0.2 \%$ or higher. The recommended rates for control of root rot and damping-off pathogens for these products are 0.6 to $0.9 \mathrm{~kg} / \mathrm{m}^{3}$ or 0.06 to $0.09 \%$ (wt/vol). However, in our tests, neither product was effective against Fusarium wilt at incorporation levels of $0.1 \%$ or below. Thus, higher levels of these antagonists apparently are necessary for adequate control of Fusarium wilt of tomato. In our assays, $0.1 \%$ incorporation corresponded to approximately 1 to $2 \times 10^{4}$ $\mathrm{CFU} / \mathrm{g}$ soilless mix or less, whereas $0.2 \%$ incorporation or higher corresponded to propagule counts of approximately 3 to $4 \times$ $10^{4} \mathrm{CFU} / \mathrm{g}$ mix and higher for both products. Nonetheless, an incorporation rate of $0.2 \%$ still involves a relatively small amount of formulated product $\left(2 \mathrm{~kg} / \mathrm{m}^{3}\right)$ and should not affect the practical use of these products for greenhouse and transplant applications. Thus, this research has also demonstrated that commercial biocontrol products already available on the market were effective in controlling Fusarium wilt of tomato. The active ingredient of RootShield had also previously been shown to reduce Fusarium crown and root rot of tomato in the field (5).

Several of the biocontrol bacterial strains of B. cepacia and Pseudomonas fluorescens provided significant reductions of disease incidence, but generally did not provide control levels greater than approximately 30 to $40 \%$ reduction, which

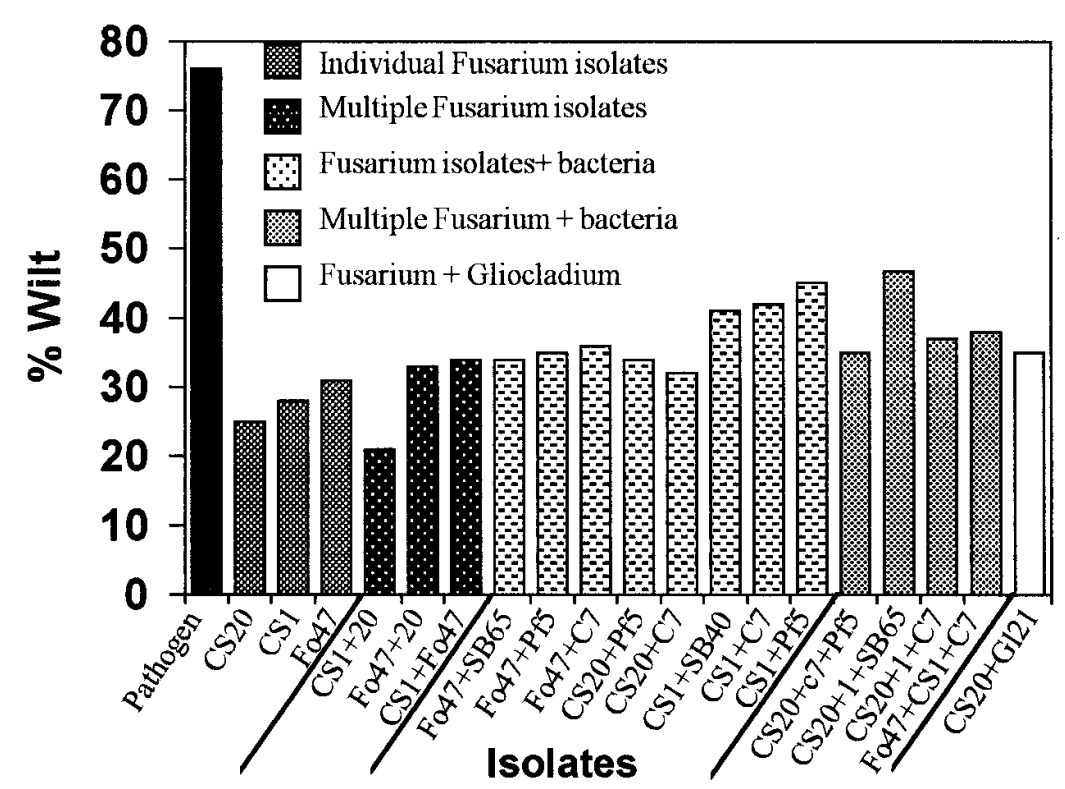

Fig. 3. Development of Fusarium wilt in tomato seedlings as affected by treatments with various combinations of biocontrol organisms. All antagonist treatments significantly reduced disease relative to the pathogen-infested control treatment according to Fisher's protected least significant difference (LSD) at $P=0.05(\mathrm{LSD}=22$ ), but there were no differences among antagonists. Other organisms tested included Cladorrhinum foecundissimum (Cf-1), Laetisaria arvalis (Zh-4), and Stilbella aciculosa (112-B2). Data represent results of a single representative test.

Table 4. Effectiveness of selected nonpathogenic strains of Fusarium spp. in controlling Fusarium wilt diseases of tomato, watermelon, and muskmelon

\begin{tabular}{|c|c|c|c|c|c|c|c|c|}
\hline \multirow[b]{2}{*}{ Isolate } & \multicolumn{2}{|c|}{ Overally } & \multicolumn{2}{|c|}{ Tomato } & \multicolumn{2}{|c|}{ Watermelon } & \multicolumn{2}{|c|}{ Muskmelon } \\
\hline & $\%$ wilt & $\%$ reduction & $\%$ wilt & $\%$ reduction & $\%$ wilt & $\%$ reduction & $\%$ wilt & $\%$ reduction \\
\hline Pathogen only & 58.7 & 0.0 & 54 & 0 & 56 & 0 & 66 & 0 \\
\hline $\mathrm{CS}-2$ & $29.3 * z$ & $50.3^{*}$ & 28 & 47 & $20 *$ & $64 *$ & 40 & 39 \\
\hline CS-10 & $24.1^{*}$ & $57.8^{*}$ & 26 & 51 & $27^{*}$ & $53 *$ & $20^{*}$ & $70^{*}$ \\
\hline CS-6 & $23.1 *$ & $60.2^{*}$ & $25^{*}$ & $54 *$ & $20 *$ & $64 *$ & $25^{*}$ & $63^{*}$ \\
\hline Fo47 & $20.4 *$ & $64.7 *$ & $24 *$ & $55^{*}$ & $20^{*}$ & $64 *$ & $17^{*}$ & $74 *$ \\
\hline CS-21 & $18.8^{*}$ & $67.4^{*}$ & $22^{*}$ & $59 *$ & $19^{*}$ & $67 *$ & $16^{*}$ & $76^{*}$ \\
\hline CS-24 & $17.3^{*}$ & $69.6^{*}$ & $25^{*}$ & $53^{*}$ & $12 *$ & $79 *$ & $16^{*}$ & $76^{*}$ \\
\hline CS-20 & $10.7 *$ & $81.5^{*}$ & $4 *$ & $92 *$ & $20 *$ & $64 *$ & $8^{*}$ & $88^{*}$ \\
\hline CS-1 & $10.6^{*}$ & $81.6^{*}$ & $11^{*}$ & $79 *$ & $10^{*}$ & $82 *$ & $11^{*}$ & $84 *$ \\
\hline
\end{tabular}

y Overall results represent combined data over all three hosts (isolate $\times$ host interactions were not significant). Disease incidence (\% wilt) is represented as the percentage of wilted plants over a 4-week period. Disease reduction (\% reduction) represents the percent reduction of disease relative to the pathogen-only control.

${ }^{\mathrm{z}}$ Values followed by an asterisk represent a significant reduction of disease relative to the pathogen-only control according to Fisher's protected least significant difference test $(P<0.05)$. 
under severe disease pressure resulted in wilt incidences of approximately 40 to $50 \%$. This level of control is comparable to those reported by others using rhizobacterial strains for the control of Fusarium wilt diseases, including those using bacterial isolates that induce resistance within the host plant $(20,31,40,46)$. However, for development as biocontrol agents, this level of disease reduction is generally not sufficient for effective and consistent disease control.

Attempts to find superior biocontrol microorganisms through isolation of tomato root-colonizing organisms were not successful in this study. Although several isolates significantly reduced disease, no tomato root isolate tested resulted in biocontrol performance as good or better than that produced by existing biocontrol strains. However, this does not suggest that this approach does not have merit. Ideally, organisms should be isolated from plants grown in fields where both tomato plants and the pathogen have been co-existing for several years (3). Such fields were not available for the present study. Fusarium wilt was not observed to be present in the fields we sampled; therefore, effective antagonist populations probably were not present or were present at such low numbers that our relatively small sample did not recover them. Approximately 20 to $25 \%$ of the isolates tested (both fungal and bacterial) showed some activity to suppress Fusarium wilt. These numbers are comparable to the percentage of antagonists isolated from soils in other studies, such as in a nonsuppressive soil in Florida (18).

The primary mechanisms of action associated with biocontrol by nonpathogenic Fusarium strains include competition, either for nutrients in the rhizosphere or infection sites on the root, and induced systemic resistance $(1,18,33)$. Isolate Fo47 has previously been shown to involve saprophytic competition as a primary mechanism of action $(1,4,21)$. Recent evidence also suggests that protection by Fo47 also involves at least some degree of induced resistance $(10,16)$. Some isolates from the Florida CSS wilt-suppressive soil, including CS-6, were previously shown to induce resistance in watermelon, as determined by split-root tests (18). Preliminary results of split-root tests using isolates CS-20 and CS-1 on tomato and watermelon indicated that these isolates also function primarily through induced resistance rather than through competition (16).

In this study, combinations of antagonist organisms, including multiple Fusarium isolates, Fusarium and bacterial strains, and Fusarium and Gliocladium strains, did not improve the level of control observed using the Fusarium isolates alone. Lemanceau and Alabouvette (22) reported improved biocontrol performance when Fusarium isolate Fo47 was used in combination with a fluorescent Pseudomonas strain (C7). Other researchers $(19,36)$ have also reported a similar enhanced response with combinations of Fusarium and Pseudomonas spp. The mechanism involves competition for carbon provided by $F$. oxysporum and competition for iron provided by the bacteria. Evidence suggests that the presence of the siderophore produced by $P$. fluorescens increases the intensity of the antagonism provided by Fo47, making the pathogen more sensitive to glucose competition by the antagonistic Fusarium $(23,24)$. However, in our tests, we did not observe this response, even in combinations using strain Fo47. This may be due to differences in the application or assay methods, or the environmental or soil conditions present. Isolates which function primarily through induced resistance instead of competition also may not show any enhanced control in combination with fluorescent pseudomonads.

Even though no improvement in disease control over that produced by $F$. oxysporum alone could be detected with the use of combinations in this study, combinations may still be advantageous for other reasons, including control of multiple pathogens, more consistent control, or control over a wider range of environmental conditions, which were not evaluated in this study. Further research on the potential advantages of using combinations of these effective antagonists under varying stress conditions is needed.

Although only a limited number of potential biocontrol isolates could be tested in this study, representative isolates of a variety of biocontrol species were tested. Several of the Fusarium isolates, particularly CS-20 and CS-1, have potential for further development as biological control agents for the control of Fusarium wilt diseases. These isolates were highly effective and consistently more effective in controlling Fusarium wilt than all other isolates tested. The level of disease control observed was also comparable or better than that reported in other studies using nonpathogenic strains of Fusarium spp. $(1,35,37,39)$, and generally better than the control reported in studies using other biocontrol organisms, such as rhizobacteria $(20,31,40,46,49)$ or other fungal antagonists $(5,6,43,49)$.

Identification of effective antagonist strains represents only the first step toward the development of effective biological control. In order for biocontrol to be implemented on a practical level, the antagonists must be ecologically fit to survive, become established, and function within the particular conditions of the ecosystem. To attain this, much more information regarding the mechanisms of action, ecological characteristics, and interactions with the soil and rhizosphere microbial communities is needed. Thus, now that we have identified several organisms as potential antagonists, we are continuing to work with these strains to determine the specific mechanisms, interactions, conditions, and requirements responsible for effective biological control. Through an understanding of these characteristics, we can establish the limitations as well as the full potential for biocontrol within this pathosystem, and develop strategies for its implementation and management.

\section{ACKNOWLEDGMENTS}

We thank C. Tate for valuable technical assistance; C. Alabouvette, K. P. Hebbar, and J. E. Loper for providing biocontrol isolates; E. Dutkey, D. L. Hopkins, and R. W. Schneider for providing pathogen isolates; and Thermo-Trilogy Corp. and Bio-Works Inc. for providing samples of their biocontrol products.

\section{LITERATURE CITED}

1. Alabouvette, C., Lemanceau, P., and Steinberg, C. 1993. Recent advances in the biological control of Fusarium wilts. Pestic. Sci. 37:365-373.

2. Burbage, D. A., Sasser, M., and Lumsden, R. D. 1982. A medium selective for Pseudomonas cepacia. (Abstr.) Phytopathology 72:706.

3. Cook, R. J. 1993. Making greater use of introduced microorganisms for biological control of plant pathogens. Annu. Rev. Phytopathol. 31:53-80.

4. Couteaudier, Y. 1992. Competition for carbon in soil and rhizosphere; a mechanism involved in biological control of Fusarium wilts. Pages 99-104 in: Biological Control of Plant Diseases: Progress and Challenges for the Future. E. C. Tjamos, G. C. Papavizas, and R. J. Cook, eds. Plenum Press, New York.

5. Datnoff, L. E., Nemec, S., and Pernezny, K. 1995. Biological control of Fusarium crown and root rot of tomato in Florida using Trichoderma harzianum and Glomus intraradices. Biol. Control 5:427-431.

6. De Cal, A., Pascual, S., Larena, I, and Melgarejo, P. 1995. Biological control of Fusarium oxysporum f. sp. lycopersici. Plant Pathol. 44:909-917.

7. Duffy, B. K., Simon, A., and Weller, D. M 1996. Combination of Trichoderma koningii with fluorescent pseudomonads for control of take-all on wheat. Phytopathology 86:188194.

8. Duffy, B. K., and Weller, D. M. 1995. Use of Gaemannomyces graminis var. graminis alone and in combination with fluorescent Pseudomonas spp. to suppress take-all of wheat. Plant Dis. 79:907-911.

9. Elad, Y., Chet, I., and Henis, Y. 1981. A selective medium for improving quantitative isolation of Trichoderma spp. from soil. Phytoparasitica 9:59-67.

10. Fuchs, J. -G., Moënne-Loccoz, Y., and Défago, G. 1997. Nonpathogenic Fusarium oxysporum strain Fo47 induces resistance to Fusarium wilt of tomato. Plant Dis. 81:492496.

11. Harman, G. E. 1991. Seed treatments for biological control of plant disease. Crop Prot. 10:166-171.

12. Hebbar, K. P., Atkinson, D., Tucker, W., and Dart, P. J. 1992. Suppression of Fusarium moniliforme by maize root-associated Pseudomonas cepacia. Soil Biol. Biochem. 24:1009-1020.

13. Jarvis, W. R. 1988. Fusarium crown and root rot of tomatoes. Phytoprotection 69:49-64.

14. Jones, J. B., Jones, J. P., Stall, R. E., and Zitter, T. A., eds. 1991. Compendium of Tomato Diseases. American Phytopathological Society, St. Paul, MN.

15. Komada, H. 1975. Development of a selective 
medium for quantitative isolation of Fusarium oxysporum from natural soil. Rev. Plant Prot. Res. 8:115-125.

16. Larkin, R. P., and Fravel, D. R. 1996. Efficacy of various biocontrol organisms in the control of Fusarium wilt of tomato. Phytopathology 86:S83.

17. Larkin, R. P., Hopkins, D. L., and Martin, F. N. 1993. Ecology of Fusarium oxysporum $\mathrm{f}$. sp. niveum in soils suppressive and conducive to Fusarium wilt of watermelon. Phytopathology 83:1105-1116.

18. Larkin, R. P., Hopkins, D. L., and Martin, F. N. 1996. Suppression of Fusarium wilt of watermelon by nonpathogenic Fusarium oxysporum and other microorganisms recovered from a disease-suppressive soil. Phytopathology 86:812-819.

19. Leeman, M., Den Ouden, F. M., van Pelt, J. A., Cornelissen, Matamala-Garros, A., Bakker, P. A. H. M., and Schippers, B. 1996. Suppression of Fusarium wilt of radish by co-inoculation of fluorescent Pseudomonas spp. and root-colonizing fungi. Eur. J. Plant $\mathrm{Pa}-$ thol. 102:21-31.

20. Leeman, M., Den Ouden, F. M., van Pelt, J. A., Hendrickx, M. J., Scheffer, R., Bakker, P. A. H. M., and Schippers, B. 1995. Biocontrol of Fusarium wilt of radish in commercial greenhouse trials by seed treatment with Pseudomonas fluorescens WCS374. Phytopathology 85:1301-1305.

21. Lemanceau, P. 1989. Role of competition for carbon and iron in mechanisms of soil suppressiveness to Fusarium wilts. Pages 385395 in: Vascular Wilt Diseases of Plants. E. C. Tjamos and C. Beckman, eds. Springer-Verlag, New York

22. Lemanceau, P., and Alabouvette, C. 1991. Biological control of fusarium diseases by fluorescent Pseudomonas and non-pathogenic Fusarium. Crop Prot. 10:279-286.

23. Lemanceau, P., Bakker, P. A. H. M., de Kogel, W. J., and Alabouvette, C. 1992. Effect of pseudobactin 358 production by Pseudomonas putida WCS358 on suppression of Fusarium wilt of carnations by nonpathogenic Fusarium oxysporum Fo47. Appl. Environ. Microbiol. 58:2978-2982.

24. Lemanceau, P., Bakker, P. A. H. M., De Kogel, W. J., Alabouvette, C., and Schippers, B. 1993. Antagonistic effect on nonpathogenic Fusarium oxysporum strain Fo47 and pseudobactin 358 upon pathogenic Fusarium oxysporum f. sp. dianthi. Appl. Environ. Microbiol. 59:74-82.

25. Lewis, J. A., Fravel, D. R., and Papavizas, G. C. 1995. Cladorrhinum foecundissimum: a potential biological control agent for the re- duction of Rhizoctonia solani. Soil Biol. Biochem. 27:863-869.

26. Lewis, J. A., Lumsden, R. D., and Locke, J. C. 1996. Biocontrol of damping-off diseases caused by Rhizoctonia solani and Pythium ultimum with alginate prills of Gliocladium virens, Trichoderma hamatum, and various food bases. Biocontrol Sci. Technol. 6:163173.

27. Lewis, J. A., and Papavizas, G. C. 1985. Effect of mycelial preparations of Trichoderma and Gliocladium on populations of Rhizoctonia solani and the incidence of damping-off. Phytopathology 75:812-817.

28. Lewis, J. A., and Papavizas, G. C. 1992. Potential of Laetisaria arvalis for the biocontrol of Rhizoctonia solani. Soil Biol. Biochem. 24:1075-1079.

29. Lewis, J. A., and Papavizas, G. C. 1993. Stilbella aciculosa: a potential biocontrol fungus against Rhizoctonia solani. Biocontrol Sci. Technol. 3:3-11.

30. Lewis, J. A., Papavizas, G. C., and Hollenbeck, M. D. 1993. Biological control of damping-off of snapbeans caused by Sclerotium rolfsii in the greenhouse and field with formulations of Gliocladium virens. Biol. Control 3:109-115.

31. Liu, L., Kloepper, J. W., and Tuzun, S. 1995. Induction of systemic resistance in cucumber against Fusarium wilt by plant growth-promoting rhizobacteria. Phytopathology 85:695698.

32. Lumsden, R. L., and Locke, J. C. 1989. Biological control of damping-off caused by $P y$ thium ultimum and Rhizoctonia solani with Gliocladium virens in soilless mix. Phytopathology 79:361-366.

33. Mandeel, Q., and Baker, R. 1991. Mechanisms involved in biological control of Fusarium wilt of cucumber with strains of nonpathogenic Fusarium oxysporum. Phytopathology 81:462-469.

34. Marois, J. J., Mitchell, D. J., and Sonoda, R. M. 1981. Biological control of Fusarium crown and root rot of tomato under field conditions. Phytopathology 71:1257-1260.

35. Minuto, A., Migheli, Q., and Garabaldi, A. 1995. Evaluation of antagonistic strains of Fusarium spp. in the biological and integrated control of Fusarium wilt of cyclamen. Crop Prot. 14:221-226.

36. Park, C. S., Paulitz, T. C., and Baker, R. 1988. Biocontrol of Fusarium wilt of cucumber resulting from interactions between Pseudomonas putida and nonpathogenic isolates of Fusarium oxysporum. Phytopathology 78:190-194.

37. Paulitz, T. C., Park, C. S., and Baker, R. 1987.
Biological control of Fusarium wilt of cucumber with nonpathogenic isolates of Fusarium oxysporum. Can. J. Microbiol. 33:349-353.

38. Pierson, E. A., and Weller, D. M. 1994. Use of mixtures of fluorescent pseudomonads to suppress take-all and improve the growth of wheat. Phytopathology 84:940-947.

39. Postma, J., and Rattink, H. 1992. Biological control of Fusarium wilt of carnation with a non-pathogenic isolate of Fusarium oxysporum. Can. J. Bot. 70:1199-1205.

40. Raaijmakers, J. M., Leeman, M., van Oorschot, M. M. P., van der Sluis, I., Schippers, B., and Bakker, P. A. H. M. 1995. Dose-response relationships in biological control of Fusarium wilt of radish by Pseudomonas spp. Phytopathology 85:1075-1081.

41. Sands, D. C., and Rovira, A. R. 1970. Isolation of fluorescent pseudomonads with a selective medium. Appl. Microbiol. 20:513-514.

42. Scher, F. M., and Baker, R. 1982. Effect of Pseudomonas putida and a synthetic iron chelator on induction of suppressiveness to Fusarium wilt pathogens. Phytopathology 72:1567-1573.

43. Sivan, A., and Chet, I. 1993. Integrated control of fusarium crown and root rot of tomato with Trichoderma harzianum in combination with methyl bromide or soil solarization. Crop Prot. 12:380-386.

44. Taylor, A. G., Harman, G. E., and Nielsen, P. A. 1994. Biological seed treatments using Trichoderma harzianum for horticultural crops. Hortic. Technol. 4:105-108.

45. UNEP Methyl Bromide Technical Options Committee. 1994. Montreal protocol on substances that deplete the ozone layer: 1994 report of the MBTOC. EPA-430/K94/029.

46. Van Peer, R., Niemann, G. J., and Schippers, B. 1991. Induced resistance and phytoalexin accumulation in biological control of Fusarium wilt of carnation by Pseudomonas sp. strain WCS417r. Phytopathology 81:1508 1512 .

47. Weller, D. M. 1988. Biological control of soilborne plant pathogens in the rhizosphere with bacteria. Annu. Rev. Phytopathol. 26:379-407.

48. Weller, D. M., and Cook, R. J. 1983. Suppression of take-all of wheat by seed treatments with fluorescent pseudomonads. Phytopathology 73:463-469.

49. Zhang, J., Howell, C. R., and Starr, J. L. 1996. Suppression of Fusarium colonization of cotton roots and Fusarium wilt by seed treatments with Gliocladium virens and Bacillus subtilis. Biocontrol Sci. Technol. 6:175-187. 